\title{
Traumatic injury of dural venous sinus as cause of epidural hematoma: importance of recognition and adequate surgical planning
}

\author{
Lesión traumática de seno dural como causa de hematoma epidural: \\ importancia de su reconocimiento y adecuada planificación quirúrgica
}

\author{
Thiago Gomes Barbosa', Leonardo Henrique da Silva Rodrigues'1, Paulo Adolfo Wessel Xander', Tiago \\ Marques Avelar', Guilherme Henrique Ferreira da Costa', Andrew Vinícius de Souza Batista', Guilherme \\ Brasileiro de Aguiar', José Carlos Esteves Veiga',
}

${ }^{1}$ Department of Surgery, Division of Neurosurgery, Santa Casa de Sao Paulo School of Medical Sciences, São Paulo. SP, Brazil.

\section{Resumen}

Aunque la mayoría de los hematomas epidurales sin de naturaleza arterial, especialmente ruptura de la arteria meningea media, alrededor del 9,7\% están asociados a una lesión venosa, implicando peor pronóstico y mayores complicaciones. Presentamos el caso de una paciente con trauma craneal y fractura de cráneo y laceración del seno transverso, que produjo un hematoma epidural, discutimos el caso y revisamos los principales aspectos de esta condición. Descripción del caso: Una hombre de 47 años es atropellado por una bicicleta, ingresado al servicio de urgencia, con una escala de Glasgow de 15 puntos, evoluciona en las siguientes 5 horas con disminución del nivel de comciencia. Una tomografía computada demostró una hiperdensidad Prieto occipital, compatible con hematoma epidural agudo, asociado a una fractura Parietoccipital que compromete el seno transverso ipsilateral. Se realiza una craneotomía Parietoccipital para evacuar el hematoma, encontrándose una lesión venosa que requirió reparación inmediata. Conclusión: Este caso y su discusión destacan las numerosos detalles técnicos que el cirujano debe considerar cuando se ve enfrentado a una hematoma epidural causado por una lesión traumática de los senos venosos, que son determinantes en la eficacia del tratamiento y pronóstico del paciente.

Palabras clave: Hematoma epidural, trauma craneo-encefálico, senos venosos durales, trauma cerebro-vascular.

\section{Abstract}

Background: Although most traumatic epidural hematomas are secondary to arterial injuries, particularly rupture of the middle meningeal artery, around $9.7 \%$ of cases are associated with dural venous sinus injury, leading to poorer prognosis and greater complications. We report a case of a patient presenting cranial trauma with bone fracture and laceration of the transverse sinus producing epidural hematoma, and discuss the main aspects of this condition. Case description: $\mathrm{A}$ 47-year-old man struck by a motorcycle was admitted to the Emergency Room with a score of 15 on the Glasgow Coma Scale, evolving over 5 hours with reduced level of consciousness. A cranial CT scan was performed disclosing right parietooccipital hyperdensity, consistent with acute epidural hematoma, and a parieto-occipital fracture line crossing the path of the ipsilateral transverse sinus. Parietal craniotomy was performed to drain the hematoma, revealing a venous sinus injury requiring immediate repair. Conclusions: This case and discussion highlight the many details and technical specificities to be taken into account by neurosurgeons when encountering intracranial hematoma caused by traumatic injury of the dural venous sinus, and which are pivotal in determining the efficacy of the treatment approach and prognosis of the patient.

Key words: Epidural hematoma, traumatic brain injury, cranial venous sinuses, cerebrovascular trauma.

Corresponding author:

Guilherme Brasileiro de Aguiar

Department of Surgery, Division of Neurosurgery Santa Casa de Sao Paulo School of Medical Sciences

Rua Dr. Cesário Motta Júnior, 61 - Vila Buarque, São Paulo - SP

CEP: 01221-020 / Telefone: 5511 3367-7700 - Telefone/Fax: 5511 3796-7007

guilhermebraguiar@yahoo.com.br 


\section{Introduction}

Cerebrum venous drainage presents the unique feature of venous channels lined by endothelium, situated between two layers of dura mater, called dura mater sinuses. Most of these sinuses have a triangular cross-section, walls that are stiffer than veins, and generally do not collapse when resected, being situated principally along the points of insertion of the folds of the dura mater.

The dural venous sinuses can become damaged both in traumatic head injuries - penetrating or cranial fractures due to blunt trauma - and by accidental lesions or those planned during craniotomy ${ }^{1}$. In the case of traumatic epidural hematoma, suspected involvement of dural sinuses calls for specific therapeutic management, involving early diagnosis, planning and adequate surgical techniques, besides post-operative follow-up focused on the common complications associated with the condition.

\section{Case report}

A 47-year-old man who sustained injury due to a road traffic accident after being struck by a motorcycle was admitted to the Emergency Room with a score of 15 on the Glasgow Coma Scale. Within 5 hours of admission, the patient deteriorated with reduced level of consciousness, requiring orotracheal intubation. A cranial Computed Tomography (CT) scan without contrast was performed and disclosed right parieto-occipital hyperdensity, consistent with acute epidural hematoma $(\mathrm{EDH})$, and a parieto-occipital fracture line traversing the path of the transverse sinus (Figure 1). Urgent surgical treatment was then indicated to drain the intracranial hematoma, with suspected involvement of the right transverse venous sinus.

In surgical planning, right parietal craniotomy was elected using horseshoe-shape incision and extended occipital arm, allowing craniotomy expansion to the posterior fossa if required (Figure 2).

The patient was placed in the dorsal decubitus position and with auxiliary roll under right shoulder and head supported in horseshoe headrest. After craniotomy and hematoma drainage, a minor lesion to the right transverse sinus was detected. The wall of the right transverse sinus was sutured using polypropylene 5-0 thread with a simple whipstitch technique, without the use of specific devices for packing.

After the surgical procedure, the patient was transferred to the Intensive Care Unit and post-operative CT showed satisfactory drainage of the hematoma (Figure 3). The patient evolved well with an early Glasgow Outcome Scale score of 4 and underwent outpatient follow-up.

\section{Discussion}

Although most EDH are secondary to arterial injuries,

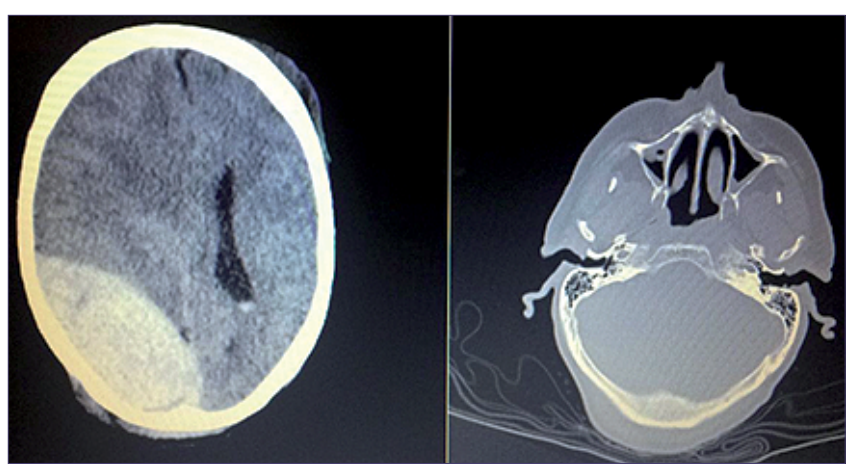

Figure 1. Cranial CT disclosing right parietooccipital EDH.

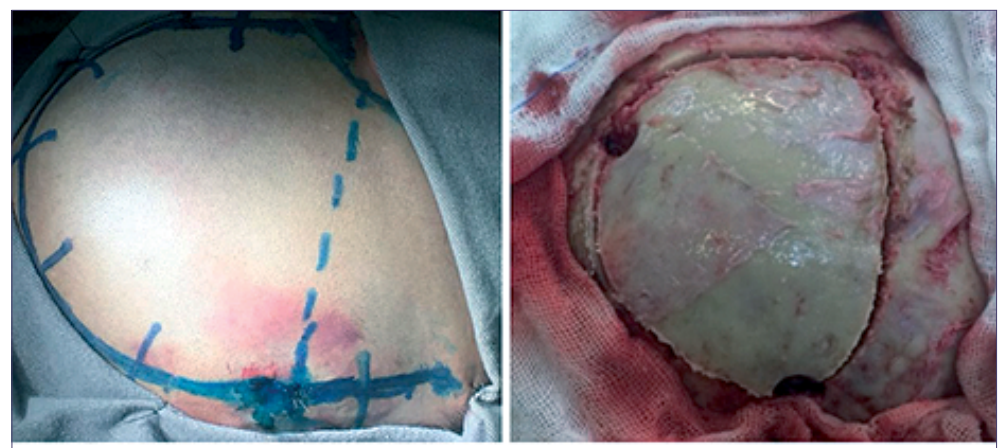

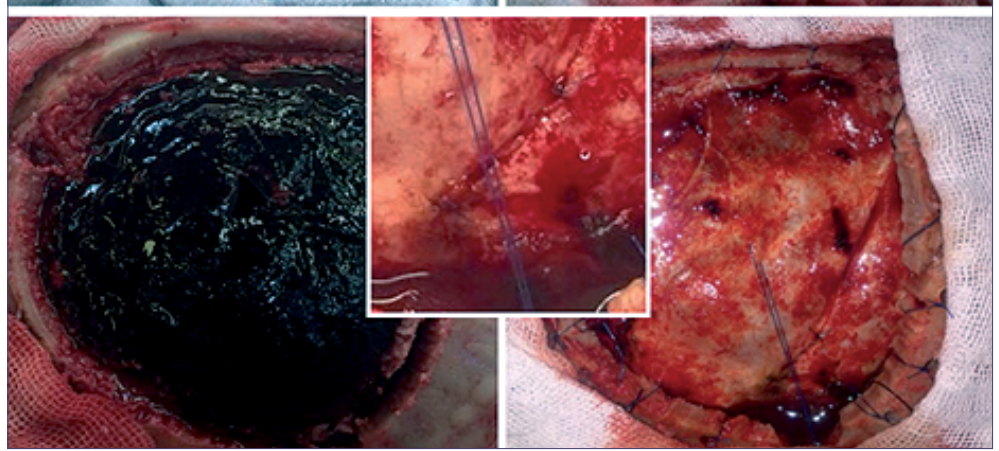

Figure 2. Marking of horseshoe incision and right parietal craniotomy. Inset depicting dural injury repair in detail. 


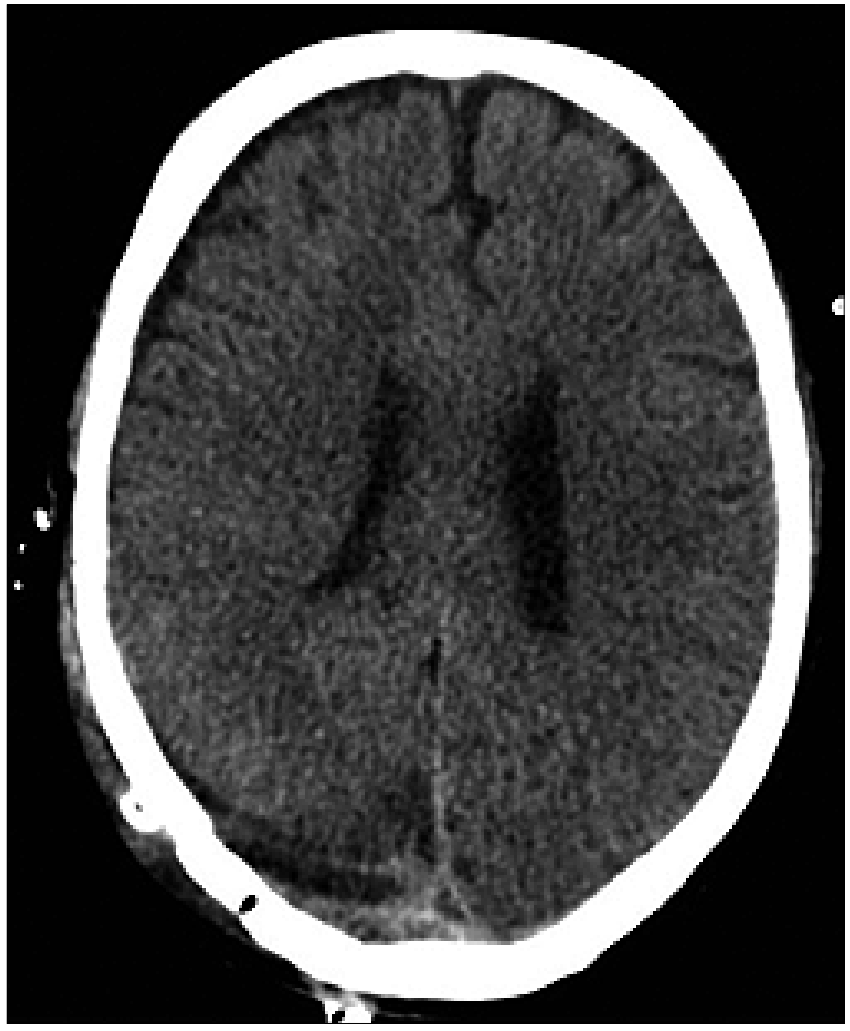

Figure 3. Post-operative control CT.

specifically due to middle meningeal artery rupture, around $9.7 \%$ of cases are associated with dural venous sinus injuries $^{2}$, leading to poorer prognosis and greater complications ${ }^{3}$. In trauma scenarios, significant injuries to the dural sinuses occur in $1-5 \%$ of all severe TBIs, predominantly involving the superior sagital sinus ${ }^{4}$. In these situations, the source of bleeding can vary depending on injury location, mechanism and severity - and may stem from the sinus roof, lateral walls, areas of confluence, arachnoid granulations, emissary veins or cortical tributary veins.

Suspected cases are evident on CT without contrast, with hematomas adjacent to or over the region of dural sinuses, with fractures traversing the sinus structures reported in up to $89 \%$ of cases $^{5}$. Posterior fossa EDH are also strongly associated with dural venous sinus involvement ${ }^{6}$. In the present case, the CT scan shows a fracture line over the transverse sinus structure (Figure 1). Performing CT with contrast is recommended prior to surgeries for depressed skull fractures over dural venous sinuses, due to the high risk of thrombosis or stenosis ${ }^{7,8}$.

Some measures should be taken in positioning and anesthesia preparation of the patient in order to prevent and/ or avert potential complications. The sinus segment affected should be at the highest point of the surgical field, where the patient should be secured on the operating table for the reverse Trendelenburg position, tilted at a $60^{\circ}$ angle so as to reduce venous pressure in intense bleedings. Measures to maximize venous drainage from the cerebrum are also necessary: reducing jugular compression using a cervical collar; avoiding excessive cervical rotation or bending; and refraining from performing ventral venous puncture in the internal jugular vein, owing to the risk of iatrogenic thrombosis of the vessel. Given the high risk of massive bleeding during the procedure, bags of packed red blood cells, fresh frozen plasma and platelets should be at the ready in the operating room ${ }^{9}$.

The negative pressure produced in the open venous sinus due to the elevation of the head relative to the heart, leads to higher risk of venous gas embolism, with "imprisonment" of air bubbles within the right atrium potentially triggering severe systolic dysfunction. It is therefore prudent to carry out intraoperative monitoring using a Capnography, precordial Doppler ultrasonography probe, and invasive arterial pressure curve. In extreme situations, puncture of the atrial gas embolism may be indicated, by catheter via brachial or subclavian vein, to resolve the condition of shock'1.

Irrespective of these peculiarities, in the case of severe dural sinus injury, surgical planning should include possible sinus segment replacement in the event that bleeding control remains refractory. Thus, materials for vascular reconstruction should be to hand for use by the neurosurgeon: temporary vascular shunt of the appropriate size, Fogarty catheters, nonabsorbable vascular suture and venous allograft. These techniques should be individualized, according to the surgeon's experience and needs ${ }^{9}$.

For lesions of the posterior $2 / 3$ of the superior sagital sinus, dominant transverse sinus and confluence of the sinuses, the patient is generally placed in the prone position using a skull clamp and "inverted U" incision, exposing the infratentorial and supratentorial compartments. The craniotomy approach is dictated by whether the target is the superior sagital sinus and confluence of the sinuses or the dominant transverse sinus alone, besides the topography of the hematoma and extent of the fracture ${ }^{8}$. In the case reported here, given the location of the hematoma, a horseshoe-shaped incision was made with an extended posterior arm to allow posterior fossa access, and a right parietal craniotomy performed over the hematoma without infratentorial extension.

The decision on surgical approach - repair or ligation, sacrificing the sinus - hinges on the injury location and extension, for which the literature provides some indications for repair (Table 1). In the case reported, the decision for repair using primary suture was based on the presence of injury to the dominant transverse sinus, involving less than $50 \%$ of the sinus lumen and of low-risk suture. Although the literature recommends using polypropylene 6-0 suture ${ }^{9}$, the repair was effected using 5-0 suture of the same material, providing equal functional gain (Figure 2).

By and large, the techniques described for repair and control of bleeding in dominant transverse sinus injuries are the same as for the superior sagital sinus injuries ${ }^{9}$. Behera et $\mathrm{al}^{4}$, outlines, in decreasing order of prevalence, the use of 4 techniques in their case series: patch with absorbable sterile gelatin hemostatic sponge $\left(\right.$ Gelfoam $\left.^{\circledR}\right)$ : compression using Gelfoam $^{\circledR}$ only; fixation with stitches over Gelfoam $^{\circledR}$; fixation by bilateral stitching over Gelfoam ${ }^{\circledR}$; and sinus rrhaphy. Other techniques reported include hemostasis and repair using TachoSil patch (human fibrinogen + human thrombin) ${ }^{10}$ and muscle tissue ${ }^{11}$; and also in patients with bilateral thrombosis of transverse sinuses, use of bypass connecting the transverse sinus to the external jugular vein employing a saphenous 
Table 1. Indications for repair of dural sinus lesions

Traumatic head injury resulting in major hemorrhage or thrombosis

Resection of neoplastic infiltration

Areas necessary for maintaining patency:

- Posterior 2/3 superior sagital sinus

- Confluence of the sinuses

- Dominant transverse sinuses

Other areas which can be ligated with minimal risk ${ }^{5}$

vein graft ${ }^{12}$.

The main post-operative complication is sinus thrombosis, especially after post-repair stenosis or extrinsic compression of the sinus, e.g. in cases of depressed bone fractures. Sinus thrombosis can lead to increased intracranial pressure, diffuse cerebral edema, intraparenchymal hemorrhages and venous infarctions, constituting an important complication to avoid.

\section{Conclusion}

The present case and discussion highlight the many details and technical specificities to be taken into account by neurosurgeons when encountering EDH caused by dural venous sinus injury, and which are pivotal in determining the efficacy of the approach and prognosis of the patient. Thus, successful surgical management entails early diagnosis, preparation of the anesthesia team, patient position on the operating table, the ideal craniotomy, the individualized choice of ligation or repair, and the best technique applicable for the patient. In any event, clinicians should remain alert to the greater risk of dural sinus thrombosis during the postoperative period.

Conflict of Interest: The authors declare that they have no conflicts of interest.

\section{References}

1. JP Kapp and I. Gielchinsky, Management of combat wounds of the dural venous sinuses, Surgery, vol. 71, no. 6, pp. 913-917, 1972

2. JLV Araujo, U. do P. Aguiar, AB Todeschini, N. Saade and JCE Veiga, Epidemiological analysis of 210 cases of surgically treated traumatic extradural hematoma, Rev Col Bras Cir, vol. 39, no. 4, pp. 268-271, 2012. https://www.scielo.br/pdf/rcbc/v39n4/ en_05.pdf doi:10.1590/S0100-69912012000400005
3. S. Yilmazlar, H. Kocaeli, S. Dogan,. F. Abas, K. Aksoy, E. Korfali and M. Doygun, Traumatic epidural haematomas of nonarterial origin: Analysis of 30 consecutive cases, Acta Neurochir (Wien), vol. 147, no. 12, pp. 1241-1248, 2005. doi:10.1007/s00701-0050623-2

4. SK Behera, SB Senapati, SS Mishra and S Das, Management of superior sagittal sinus injury encountered in traumatic head injury patients: Analysis of 15 cases, Asian J Neurosurg, vol.10, no.1, pp. 17-20, 2015. doi: 10.1007/s00701-005-0623-2.

5. KL Pricola, H. Zou and SD Chang, Successful repair of a gunshot wound to the head with retained bullet in the torcular herophili, World Neurosurg, vol. 76, no. 3-4), pp. e361-364, 2011. doi: 10.1016/j.wneu.2010.03.021

6. E. Bor-Seng-Shu, PH Aguiar, RJ de Almeida Leme, M. Mandel, AF Andrade and R. Marino Jr, Epidural hematomas of the posterior cranial fossa, Neurosurg Focus, vol. 16, no. 2, pp. ECP1, 2004. doi: 10.3171/foc.2004.16.2.10

7. KC Rao, HC Knipp and EJ Wagner, Computed tomographic findings cerebral sinus and venous thrombosis, Radiology, vol. 140, no. 2, pp. 391-398, 1981. doi: 10.1148/radiology.140.2.7255715.

8. JA Forbes, AS Reig, LD Tomycz, N and Tulipan, Intracranial hypertension caused by a depressed skull fracture resulting in superior sagittal sinus thrombosis in a pediatric patient: treatment with ventriculoperitoneal shunt insertion, J Neurosurg Pediatr, vol. 6, no. 1, pp. 23-28, 2010. doi: 10.3171/2010.3.PEDS09441

9. JS Ullman and PB Raksin, Atlas of Emergency Neurosurgery, Thieme Medical Publishers, Inc. 2015.

10. R. Gazzeri, M. Galarza, C. Fiore, G. Callovini and A. Alfieri, Use of tissue-glue-coated collagen sponge (TachoSil) to repair minor cerebral dural venous sinus lacerations: technical note, Neurosurgery, vol. 11, no. 1, pp. 32-36, 2015. doi: 10.1227/ NEU.0000000000000614.

11. SQ Huang, Surgical treatment of intracranial venous sinus injury. A report of 111 cases, Zhonghua Wai Ke Za Zhi, vol. 27, no. 3, pp. 166-8, 190, 1989.

12. M. Sindou, P. Mercier, J. Bokor and J. Brunon, Bilateral thrombosis of the transverse sinuses: microsurgical revascularization with venous bypass, Surg Neurol, vol. 13, pp. 215-220, 1980. 